\title{
Coexistence of Pelviureteric Junction Obstruction and Vesicoureteral Reflux
}

\author{
Md. Asaduzzaman ${ }^{* 1}$, SM Abdullah ${ }^{2}$, Mohammad Abu Hanif ${ }^{3}$, \\ Md. Hasanuzzaman ${ }^{4}$, Rifat Naoreen Islam ${ }^{5}$, Shahnoor Islam ${ }^{6}$
}

\begin{abstract}
Introduction: The most common upper urinary tract problem in children is obstruction at the pelviureteric junction. It happens with varying degrees of seriousness. Ultrasonography and DTPA (Diethylene Triamine Penta-acitic Acid) renography are commonly used to detect it. Objective: To find out the coexistence of ipsilateralpelviureteric junction obstruction with vesicourenteral reflux. Materials and Methods: This prospective study was conducted in the Department of Paediatric Surgery, Bangabandhu Sheikh Mujib Medical University (BSMMU), Dhaka, Bangladesh from January 2006 to May 2007 over a period of 1 year 5 months. Thirty-five patients with unilateral hydronephrosis due to PUJ obstruction were included in this study (age: 1 month-15 years). Results were analyzed using Statistical Package for Social Science (SPSS). Results: Incidence of Vesicoureteral reflux (VUR) among pelviureteric junction (PUJ) obstruction patients was $8.6 \%$. Of them Grade-I VUR was 33.3\% and grade-II VUR was $66.7 \%$. Mean age of the patients was $4.71 \pm 1.97$ years and with VUR was $9.33 \pm 4.93$ years. Male to female ratio was $4: 1$. Only 5.7\% mothers had regular antenatal checkup and $28.5 \%$ had irregular. Majority of the patients 28 (80\%) were presented with painless loin mass, $6(17.1 \%)$ with fever, $8(22.9 \%)$ with loin pain and $8(22.9 \%)$ with failure to thrive. Three patients (8.6\%) showed abnormal $R / M / E$ and all of the abnormal $R / M / E$ samples showed positive culture. Conclusions: Incidence of Vesicoureteral reflux (VUR) among pelviureteric junction (PUJ) obstruction patients was $8.6 \%$.
\end{abstract}

Keywords: Vesicoureteral reflux (VUR), Pelviureteric junction (PUJ).

Number of Tables: 07; Number of References: 22; Number of Correspondence: 07.

*1. Corresponding Author: Dr. Md. Asaduzzaman

Assistant Professor

Department of Pediatric Surgery

Dhaka Medical College \& Hospital, Dhaka.

E-mail:asadap69@gmail.com

2. Dr. SM Abdullah

Assistant Professor

Department of Pediatric Surgery

Abdul Malek Ukil Medical College, Noakhali.

3. Dr. Mohammad Abu Hanif

Assistant Professor

Depatment of General Surgery

Sheikh Hasina Medical College \& Hospital, Tangail.

4. Dr. Md. Hasanuzzaman

Assistant Professor

Department of Pediatric Surgery

Dhaka Medical College, Dhaka.

\section{Dr. Rifat Naoreen Islam}

Associate Professor

Department of Forensic Medicine

Medical College for Women and Hospital, Dhaka.

6. Prof. Dr. Shahnoor Islam

Professor

Department of Pediatric Surgery

Dhaka Medical College \& Hospital, Dhaka.

\section{Introduction:}

Obstruction at the pelviureteric junction is the commonest problem of the upper urinary tract in children. It occurs with all degrees of severity $^{1,2}$. It is usually detected by ultrasonography and DTPA (DiethyleneTriaminePenta-acitic Acid) renography ${ }^{3}$. In most cases, a congenital intrinsic lesion is responsible for the pelviureteric junction obstruction ${ }^{4}$.

The overall incidence of pelviureteric junction (PUJ) obstruction approximates 1 in 1500 . The ratio of male to female is $2: 1$ in the neonatal period, with left-sided lesions occurring in 60 percent ${ }^{5}$.

Vesicoureteral reflux (VUR) is the common abnormal condition of the child's lower urinary tract. VUR is a dynamic event, the retrograde flow of urine from the bladder to the upper urinary tract ${ }^{6}$. This anomaly is considered primary when there is no demonstrable urinary out flow obstruction ${ }^{7}$. Primary reflux results from mal development or delayed maturity of VUJ. PUJ may be distorted by changes in the bladder wall secondary to other pathology, called secondary reflux. In both situations the pathophysiological consequences of VUR are the same in exposing the kidneys to pressure changes and urine, normally confined to the bladder ${ }^{8}$.

In 2001, Yeung and colleagues ${ }^{9}$ have shown that low-grade reflux coexists with pelviureteric junction obstruction. When pelviureteric junction obstruction coexists with vesico ureteral reflux both operation may be necessary ${ }^{1}$.

Voiding cystourethrography (VCUG) is the standard diagnostic investigation for $\mathrm{VUR}^{8}$. Nuclear cystogram can also be used as diagnostic tool. But conventional VCUG has some advantages over 
nuclear cystogram- it can also diagnose other VUR problems and posterior urethral valves; it yields other details of bladder anatomy and function that the nuclear cystomgram does not; it stages the severity of reflux more accurately and it detects reflux in a duplex system ${ }^{10}$.

A voiding cystourethrogram should always be obtained in case of PUJ obstruction to look for the presence or absence of vesicoureteral reflux. Sever reflux and subsequent ureteral ectasia may kink the PUJ and cause delayed drainage of the pelvis. Milder degrees of reflux may also be seen concomitant with PUJ obstruction ${ }^{11}$.

\section{Materials and Methods:}

This prospective study was carried out in the Department of Paediatric Surgery, Bangabandhu Sheikh Mujib Medical University (BSMMU), Dhaka, Bangladesh from January 2006 to May 2007 over a period of 1 year 5 months. Thirty-five patients with unilateral hydronephrosis due to PUJ obstruction were included in this study (age: 1 month-15 years). Patients suffering from parenchymal renal disease, bilateral hydronephrosis and patients with solitary kidney were excluded from this study. All the selected patients underwent voidingcystourethrougraphy on the Radiology and Imaging Department of Bangabandhu Sheikh Mujib Medical University. Results were analyzed using Statistical Package for Social Science (SPSS).

\section{Results:}

Nineteen patients were $<5$ years $(54.2 \%)$ and $45.7 \%$ were $\geq 5$ years old. All of the VUR patients were $\geq 5$ years old. Males were predominant than females. Male to female ratio was 4:1 (Table-I).

Table-I: Incidence of VUR in PUJ obstruction patients $(\mathrm{N}=35)$.

\begin{tabular}{lcc}
\hline VUR & Frequency (n) & Percentage (\%) \\
\hline Present & 3 & 8.6 \\
Absent & 32 & 91.4 \\
Grade of VUR & 1 & 33.3 \\
$\quad$ Grade-I & 2 & 66.7 \\
$\quad$ Grade-II & & \\
\hline
\end{tabular}

Incidence of Vesicoureteral reflux (VUR) among pelviureteric junction (PUJ) obstruction patients was 8.6\%. Of them Grade-I VUR was $33.3 \%$ and grade-II VUR was $66.7 \%$.

Table II: Demographic profile of the patient $(\mathrm{N}=35)$.

\begin{tabular}{|c|c|c|c|c|}
\hline & \multirow[t]{2}{*}{ Total } & \multicolumn{2}{|l|}{ VUR } & \multirow[t]{2}{*}{ p-value } \\
\hline & & Present & Absent & \\
\hline \multicolumn{5}{|l|}{ Age } \\
\hline$<5$ & $19(54.2)$ & $0(0.0)$ & $19(59.4)$ & 0.085 \\
\hline$\geq 5$ & $16(45.7)$ & $3(100.0)$ & $13(40.6)$ & \\
\hline Mean \pm SD & $4.71 \pm 1.97$ & $9.33 \pm 4.93$ & $4.28 \pm 1.70$ & $<0.001$ \\
\hline Min - $\max$ & $0.08-15$ & $6-15$ & $0.08-9$ & \\
\hline \multicolumn{5}{|l|}{ Gender } \\
\hline Male & $28(80.0)$ & $3(100.0)$ & $25(78.1)$ & 1.000 \\
\hline Female & $7(20.0)$ & $0(0.0)$ & $7(21.9)$ & \\
\hline
\end{tabular}

Left sided hydronephrosis was $66.7 \%$ and right sided $33.3 \%$ among VUR patients (Table-III).
Table -III: Side of hydronephrosis of the patient $(\mathrm{N}=35)$.

\begin{tabular}{lcccc}
\hline \multirow{2}{*}{$\begin{array}{l}\text { Side of } \\
\text { hydronephrosis }\end{array}$} & \multirow{2}{*}{ Total } & \multicolumn{2}{c}{ VUR } & \multirow{2}{*}{ p-value } \\
\cline { 3 - 4 } & & Present & Absent & \\
\hline Left & $25(71.4)$ & $2(66.7)$ & $23(71.9)$ & 1.000 \\
Right & $10(28.6)$ & $1(33.3)$ & $9(28.1)$ & \\
\hline
\end{tabular}

Ten mothers $(28.5 \%)$ had history of irregular antenatal, 23 mothers $(65.8 \%)$ had no antenatal checkup and only two mothers had regular antenatal checkup (5.7\%) (Table-IV).

Table -IV: Antenatal checkup of the mother of the patient $(\mathrm{N}=35)$.

\begin{tabular}{lcc}
\hline & Frequency (n) & Percentage (\%) \\
\hline No checkup & 23 & 65.8 \\
Irregular & 10 & 28.5 \\
Regular & 2 & 5.7 \\
\hline
\end{tabular}

Majority of the patients $28(80 \%)$ were presented with painless loin mass, $6(17.1 \%)$ with fever, $8(22.9 \%)$ with loin pain and $8(22.9 \%)$ with failure to thrive (Table-V).

Table -V: Clinical presentation of the patient $(\mathrm{N}=35)$.

\begin{tabular}{lcc}
\hline Clinical presentation & Frequency (n) & Percentage (\%) \\
\hline Painless loin mass & 28 & 80.0 \\
Loin pain & 8 & 22.9 \\
Failure to thrive & 8 & 22.9 \\
Fever & 6 & 17.1 \\
\hline
\end{tabular}

Palpable kidney was the commonest physical finding $(80.0 \%)$ followed by pallor $(17.1 \%)$ and only one patient $(2.9 \%)$ was associated with distal penile hypospaedias (Table-VI).

Table-VI: Physical finding of study patients $(n=35)$.

\begin{tabular}{lcc}
\hline Physical findings & Frequency (n) & Percentage (\%) \\
\hline Palpable kidney & 28 & 80.0 \\
Pallor & 6 & 17.1 \\
Associate anomaly & 1 & 2.9 \\
\hline
\end{tabular}

Three patients $(8.6 \%)$ showed abnormal R/M/E and all of the abnormal $\mathrm{R} / \mathrm{M} / \mathrm{E}$ samples showed positive culture. Rests of the 32 patients (91.4\%) showed normal R/M/E and negative $\mathrm{C} / \mathrm{S}$ (Table-VII).

Table-VII: Microscopic examination of urine and culture sensitivity $(n=35)$.

\begin{tabular}{ccc}
\hline & Frequency (n) & Percentage (\%) \\
\hline Urine R/M/E & 32 & 91.4 \\
Normal & 3 & 8.6 \\
Abnormal & 32 & \\
Urine C/S & 3 & 91.4 \\
Negative & 8.6 \\
Positive & 32 \\
\hline
\end{tabular}

\section{Discussion:}

PUJ obstruction is the commonest cause of hydronephrosis in pacdiatric. It is usually diagnosed by ultrasonography and renal $\operatorname{scan}^{3}$.

Nineteen study subjects were $<5$ years $(54.2 \%)$ and $45.7 \%$ were $\geq 5$ years old. All of the VUR patients were $\geq 5$ years old. This finding is consistent with the findings of others) ${ }^{12,13}$. Males were predominant than females. Male to female ratio was $4: 1$. In one series male to female ratio was $4.5: 1^{12}$. 
Majority of the mothers $(65.8 \%)$ of this study had no antenatal checkup at all, 10 (28.5\%) had irregular checkup and only two mothers (5.7\%) had regular antenatal checkup.

Majority of the patients of this study $(80.0 \%)$ presented with a painless loin mass. This finding is not consistent with the findings of western countries where most of the cases were diagnosed by antenatal $\mathrm{USG}^{10}$. Here patients also had fever $(17.1 \%)$, loin pain $(22.9 \%)$ and failure to thrive $(22.9 \%)$. This observation also matched with that of Rodriguez and his co-workers ${ }^{14}$.

In this study, $25(71.4 \%)$ cases were of left sided and 10 $(28.6 \%)$ cases were of right sided pelviureteric junction obstruction. It may indicate that congenital PUJ obstruction predominantly affects left sided kidney. This finding is consistent with other studies where $2 / 3 \mathrm{rd}$ of cases were left sided $^{3,10,14}$. In the present study out of 3 patient 2 cases were of left-sided VUR and 1 case were of right sided. It may indicate that VUR with PUJ obstruction predominantly occur left-sided kidney. This finding is consistent with other studies where $2 / 3$ rd of cases were left sided ${ }^{10}$.

Among them, 3 showed features of UTI (pus cell $>10 / \mathrm{HPF}$ in $\mathrm{R} / \mathrm{M} / \mathrm{E}$ of urine) and their culture revealed, growth of E.coli $\left(\mathrm{CFU}>1 \times 10^{5}\right)$. In rest of the 32 cases urinalysis reports were normal. Urine became sterile after using a course of sensitive antibiotic in all the infected case.

Incidence of Vesicoureteral reflux (VUR) among pelviureteric junction (PUJ) obstruction patients was $8.6 \%$. Of them Grade-I VUR was $33.3 \%$ and grade-II VUR was $66.7 \%$. This result indicates that PUJ obstruction co-exist with VUR. In one series the co-existence was $14.0 \%{ }^{15}$ and another series that was $8.5 \%{ }^{16-19}$.

This study demonstrates that Hydronephrosis due to pelviureteric junction obstruction coexist with VUR so voiding cystourethrography is routinely recommended to detect vesico ureteral reflux is children with uretero pelvic junction obstruction ${ }^{20-22}$.

\section{Conclusion:}

From this study, it can be concluded that there is coexistence of pelviureteric junction obstruction with low grade ipsilateral VUR. And a routine voiding cystourethrography can be recommended to detect VUR in children with uretero pelvic junction obstruction.

\section{Conflict of Interest: None.}

\section{Acknowledgement:}

We are grateful to Professor. Dr. Md. Ashraf U1 Huq, Professor and Head of the Department of Pediatric Surgery, Dhaka Medical College \& Hospital to give us full support to complete this research work.

\section{References:}

1. Lebowitz RL, Blickman JG. The coexistence of ureteropelvic junction obstruction and reflux. American Journal of Roentgenology. 1983 Feb 1;140(2):231-8.

https://doi.org/10.2214/ajr.140.2.231

PMid:6600335
2.Wang Y, Puri P, Hassan J, Miyakita H, Reen DJ. Abnormal innervation and altered nerve growth factor messenger ribonucleic acid expression in ureteropelvic junction obstruction. The Journal of urology. 1995 Aug;154(2): 679-83.

https://doi.org/10.1016/S0022-5347(01)67132-5

3. Imaji R, Dewan PA. Calyx to parenchyma ratio in pelvi-ureteric junction obstruction. BJU international. 2002 Jan;89(1):73-7.

https://doi.org/10.1046/j.1464-410X.2002.02543.x

4. Hanna MK, Jeffs RD, Sturgess JM, Barkin M. Ureteral structure and ultrastructure. Part II. Congenital ureteropelvic junction obstruction and primary obstructive megaureter. The Journal of urology. 1976 Dec 1;116 (6):725-30.

https://doi.org/10.1016/S0022-5347(17)58987-9

5.Peters, CA and Roth, JA. Congenital urine flow impairments of the upper urinary tract: Pathophysio logy and experimental studies, in JP Gearhart. CR Rink, PDE Mouriquand (eds). Pediatric urology. WB Saunders; USA. 2001; 3Q3-316.

6. Denes FT, Arap S. Vesicoureteral reflux in children. Jornal de pediatria. 1995;71(4):183-8.

https://doi.org/10.2223/JPED.775

PMid:14688999

7. Goonasekera, CDA and Abcysekera, CK. Vesicoureteric reflux \& Relfux nephropathy. Indian Journal of Pediatrics. 2003;(70): 241-249.

https://doi.org/10.1007/BF02725592

PMid:12785297

8. Godley ML. Vcsicourctcral Reflex; Pathophysiology and experimental studies in JP Gearhart. CR Rink \& PDE Mouriquand (cds). Pediatric urology. Philadelphia, USA: WB Saunders company; 2001: 359-382.

9.Yeung, KC. Tathophysiology of Bladder dysfunction, in JP Gearhart. CR Rink, PDE Mouriquand (eds). Pediatric urology. USA: WB Saunders company; 2001: 453-469.

10.Churchill, BM and Feng. WC,PeIviureteric Junction Anomalies: ongenital PUJ problems in children in JP Gearhart. CR Rink \& PDE Mouriquand (eds). Pedialric urology. Philadelphia, US: WB Saunders company; 2001: 318-346.

11.Anderson, GF. Urinary tract obstruction. In: MM Ziegler, RG, Aziz Khan \&TR Weber (eds). Operative pedialric surgery. USA: The McGraw-Hill Companies; 2003: 871-885.

12. Rashid, MA. A clinical sludy on presentation and management of hydroncphrosis in children, MS, Thesis, University of Dhaka; 1996: 75-79.

13.Hafez AT, McLorie G, Bägli D, Khoury A. Analysis of trends on serial ultrasound for high grade neonatal hydronephrosis. The Journal of urology. 2002 Oct 


\section{1;168(4):1518-21.}

https://doi.org/10.1016/S0022-5347(05)64508-9

14.Rodríguez LV, Lock J, Kennedy WA, Shortliffe LM. Evaluation of sonographic renal parenchymal area in the management of hydronephrosis. The Journal of urology. 2001 Feb;165(2):548-51.

https://doi.org/10.1097/00005392-200102000-00066

PMid:11176432

15.Hollowell JG, Altman HG, Snyder HM, Duckett JW. Coexisting ureteropelvic junction obstruction and vesicoureteral reflux: diagnostic and therapeutic implications. The Journal of urology. 1989 Aug;142(2 Part 2):490-3.

https://doi.org/10.1016/S0022-5347(17)38793-1

16.Kim YS, Do SH, Hong CH, Kim MJ, Choi SK, Han SW. Does every patient with ureteropelvic junction obstruction need voiding cystourethrography? The Journal of urology. 2001 Jun;165(6 Part 2):2305-7.

https://doi.org/10.1016/S0022-5347(05)66190-3

17. Kajbafzadeh AM, Tourchi A, Ebadi M. The outcome of initial endoscopic treatment in the management of concomitant vesicoureteral reflux and ureteropelvic junction obstruction. Urology. 2013 May 1;81(5):1040-6.

https://doi.org/10.1016/j.urology.2013.01.036

PMid:23608426
18. Sharma N, Bajpai M, Panda SS. Pelviureteric Junction Obstruction Associated with Vesico-ureteric reflux and Vesico-ureteric Junction Obstruction: challenges and. J ProgPaediatr Urol. 2014 Jan;17(1):24-7.

19. Pastore V, Aceto G, Niglio F, Basile A, Cocomazzi R, Faticato MG, et al. Clinical characteristics and management of children with ureteropelvic junction obstruction and severe vesicoureteral reflux: preliminary results. Annals of Pediatric Surgery. 2013;9(3):114-6.

https://doi.org/10.1097/01.XPS.0000430523.83127.93

20. Weitz M, Schmidt M. To screen or not to screen for vesicoureteral reflux in children with ureteropelvic junction obstruction: a systematic review. European journal of pediatrics. 2017 Jan;176(1):1-9.

https://doi.org/10.1007/s00431-016-2818-3

PMid:27888411

21. Han W, Song H, Zhang W, Sun N, Huang C. The experience of diagnosis and mangement in coexisting ureteropelvic junction obstruction and nonrefluxmegaureter. Chinese Journal of Urology. 2017 Jan 1;38(2):95-8.

22. Hegde S, Menon P, Rao KL. Co-existing pediatric ureteropelvic junction obstruction and vesicoureteric reflux: Prevalence and implications. Journal of Indian Association of Pediatric Surgeons. 2019 Apr;24(2):109.

https://doi.org/10.4103/jiaps.JIAPS_37_18

PMid:31105396 PMCid:PMC6417044 